This PDF is a selection from an out-of-print volume from the National Bureau of Economic Research

Volume Title: International Volatility and Economic Growth: The First Ten Years of The International Seminar on Macroeconomics

Volume Author/Editor: Georges de MÃ@nil and Robert J. Gordon, editors

Volume Publisher: Elsevier Science Publishers B.V., 1991

Volume ISBN: 0-444-89284-2

Volume URL: http://www.nber.org/books/de_m91-2

Conference Date: various

Publication Date: January 1991

Chapter Title: Domestic Saving and International Capital Movements in the Long Run and the Short Run

Chapter Author: Martin Feldstein

Chapter URL: http://www.nber.org/chapters/c11685

Chapter pages in book: (p. 331 - 353) 


\title{
DOMESTIC SAVING AND INTERNATIONAL CAPITAL MOVEMENTS IN THE LONG RUN AND THE SHORT RUN*
}

\author{
Martin FELDSTEIN \\ NBER, and Harvard University, Cambridge, MA 02138, USA
}

\section{Introduction}

A nearly universal assumption in international economic analysis is that capital flows freely among countries to keep the return to capital equal in all places. The implications of this assumption of perfect capital mobility are not only extremely important but are also contrary to most economists' beliefs about the behavior of national economies. Perfect capital mobility implies, for example, that the burden of corporate income taxes falls primarily on labor, that government deficits do not crowd out private investment, that increases in saving do not raise domestic investment, and that monetary and tax policies cannot alter the real net rate of return on domestic capital. To avoid such intellectual schizophrenia, we must either modify the assumption of perfect capital mobility or abandon the view that national monetary and fiscal policies that alter domestic saving can thereby influence the process of domestic capital formation.

An alternative view of the international economy recognizes that capital mobility is less perfect. Capital tends to flow in the direction of higher returns but risk considerations, institutional barriers and government policies impede that flow. For private lenders and portfolio investors, foreign stocks and bond are a very imperfect substitute for domestic securities. The profitability of foreign direct investment reflects not only the factor proportions in the host country but also firm-specific considerations of marketing, tariff barriers, tax rules, etc. Foreign direct investment also involves political risks that are fundamentally different from investing in the home country. Further, government policies may seek to encourage or prevent capital inflows or outflows during long periods of time. These restrictions on perfect capital mobility imply that national economic policies that affect domestic saving can also influence domestic capital formation.

In an earlier paper, Charles Horioka and I presented a direct test of the

*The research is part of the Bureau's project on Productivity and Industrial Change in the World Economy. I am grateful to Glenn Hubbard for assistance with this work and the several colleagues, especially Jeffrey Sachs, for discussions. 
perfect capital mobility assumption [Feldstein and Horioka (1980)]. We reasoned that with perfect capital mobility there should be no relation between a country's domestic saving rate and its domestic rate of investment. Instead, a sustained increase in saving in any one country should add funds to the world capital market. These funds would then be divided among countries in a way that depends on the relative size of each country's initial capital stock and the elasticity of its marginal efficiency of capital schedule, but that does not depend on which country did the additional saving.

We used data for the industrial countries that are members of the Organization for Economic Cooperation and Development (OECD) to test this implication of perfect capital mobility. We showed first that there are substantial differences in domestic saving rates among these countries and that these differences remain stable over a long period of time. We then estimated regression equations relating the ratio of domestic investment to gross domestic product as the dependent variable to the ratio of domestic saving to GDP as the independent variable. To reduce the impact of cyclical variations and random shocks, both variables were averaged over a minimum of five years.

The evidence overwhelmingly rejected the implication of perfect capital mobility. The relation between the investment ratio and the savings ratio is significantly different from zero in every period that we examined at significance levels that were always less than 0.001. Indeed, the coefficients were always greater than 0.85 and within two standard errors of 1.0. The conclusion was unavoidable that, contrary to the implication of the perfect capital mobility assumption, a sustained increase in the domestic saving ratio caused an almost equal increase in the domestic investment ratio.

The Feldstein-Horioka analysis explicitly assumed that intercountry differences in savings rates are caused by differences in demographic structure, population growth rates and social security retirement income programs. This specification, based on earlier work by Modigliani (1970) and Feldstein (1977), permitted using a simultaneous equations approach to estimating the investment equation with the savings ratio treated as endogenous. These estimates confirmed the ordinary least squares results. ${ }^{1}$

The findings of the Feldstein-Horioka study should not however be overinterpreted. They do not imply that there is no capital mobility nor that there is no tendency of capital to shift toward countries where it can earn a high after-tax rate of return. ${ }^{2}$ Strictly interpreted, the Feldstein-Horioka paper only claims to be a test of the extreme hypothesis of perfect capital mobility. More generally, however, it is reasonable to interpret the Feldstein-

\footnotetext{
'The Feldstein-Horioka paper also reported several other tests that will not be repeated here, e.g., adding variables measuring country size and openess to the investment equation. Section 4 of the present paper returns to the problem of simultaneity.

${ }^{2}$ Frisch (1981) and Hartman (1981) present some evidence that investment flows are sensitive to after-tax rates of return.
} 
Horioka findings as evidence that there are substantial imperfections in the international capital market and that a very large share of domestic savings tends to remain in the home country. This implies further that sustained government deficits do reduce domestic capital formation and that corporate income taxes can reduce the net return to capital. ${ }^{3}$

The Feldstein-Horioka study used data for the fifteen year period from 1960 through 1974. The sample period ended just as the dramatic 1973 OPEC price increase had begun to alter substantially the current account deficits of the industrial nations and therefore the international flow of capital. Government interference with international capital movements was also reduced in some countries in the 1970s; the United States, for example, ended its interest equalization tax on foreign borrowing in the United States in 1974, and reduced the pressure on U.S. multinationals to finance overseas investment by borrowing abroad.

One major purpose of the present study is to extend the sample period to the end of the 1970s. The evidence presented in section 2 confirms that the second half of the 1970s was a period of substantially greater international capital flows. Nevertheless, the earlier finding that international differences in saving rates are associated with nearly equal differences in investment rates is reconfirmed. There is no more support for the perfect capital mobility hypothesis in the regression estimates for 1974 through 1979 than there was in the previous fifteen years.

Since net foreign investment is equal to the difference between domestic savings and domestic investment, the strong association between domestic investment and domestic savings implies that there is only a weak association between net foreign investment and domestic savings. The empirical analysis presented in section 3 decomposes net foreign investment and examines the relation between each of the major components of net foreign investment and the domestic saving rate. A different type of decomposition is suggested by the essential equality of net foreign investment and the current account surplus. Section 3 also examines the relation between the components of the current account balance and the domestic

${ }^{3}$ I interpret Harberger (1980) as essentially accepting this interpretation. In an earlier paper [Harberger (1978)], he argued that international capital markets were essentially perfect and therefore that rates of returns are equalized internationally just as 'water seeks its own level'. But by his 1980 paper, Harberger concludes: 'My own intuition does not want to accept the notion that increments of investment activity are in all or nearly all countries effectively 100 percent 'financed' by funds flowing in from abroad, and that increments in saving simply spill out into the world capital markets. I find the analogy to a hydraulic system with perhaps a viscous fluid, in which the pipes are partially clogged, and in which some vessels are separated by semipermeable membranes, to be more consonant with my image of the world than the alternative analogy to a hydraulic system where the water flows freely through the system and, essentially instantaneously, finds the same level everywhere' (p. 336). If that flow is slow enough, so that the tendency toward equalization must be measured in decades rather than months or even years, any relevant analysis must regard the capital movements as incomplete and rates of return as potentially unequal. 
saving rate. Neither of these analyses suggests any change in the basic conclusion about the long-run independence of international capital flows from domestic savings rates.

Since domestic savings and domestic investment are parts of an interdependent economic system, the regression of investment ratios on savings ratios raises problems of estimation and interpretation. Section 4 discusses the issues of identification and estimation with the help of a minimal theoretical model of investment, savings and international capital flows. The analysis indicates why cross-country data averaged over substantial periods are likely to be a much more reliable basis for testing the hypothesis of perfect capital mobility and for estimating structural paramenters than time series data for individual countries.

Section 5 then examines an explicit model of portfolio choice that shows why sustained changes in domestic savings may have only a small effect on net foreign investment in the long run and yet may also have a more substantial effect on capital flows in the short run.

There is a brief concluding section that comments on some of the limitations of the current paper and that suggests direction for future research.

\section{The effect of saving on domestic investment}

The basic data for the present analysis are the ratios of investment to GDP and savings to GDP for seventeen OECD countries. ${ }^{4}$ These ratios are calculated using the current dollar magnitudes published by the OECD (1981) and therefore adjusted by the OECD to a common set of statistical definitions.

Table 1 presents the values of the saving and investment ratios and of the differences between them. All of the figures refer to gross investment and saving. The first three columns show the mean values of these ratios for each country in the 15-year period from 1960 through $1974 .^{5}$ The comparable ratios for the post-OPEC years 1975 through 1979 are shown in the next three columns.

These figures show a striking increase in the absolute differences between the domestic savings rate and the domestic investment rate. In the fifteen years ending in 1974, the difference between the average savings ratio and the average investment ratio ranged from -0.030 (in Greece) to 0.018 (in the Netherlands) with a mean of 0.007 and a standard deviation of 0.016 . in contrast, in the second half of the 1970 s the range was from -0.042 (in

\footnotetext{
${ }^{4}$ The other seven OECD countries had to be excluded from the sample because consistent data are not available for the entire period.

${ }^{5}$ These ratios differ from the ratios presented in table 1 of Feldstein and Horioka (1980) only because of data revisions.
} 
Table 1

Savings and investment ratios in OECD countries."

\begin{tabular}{|c|c|c|c|c|c|c|}
\hline & \multicolumn{3}{|c|}{ Mean values, $1960-1974$} & \multicolumn{3}{|c|}{ Mean values, 1975-1979 } \\
\hline & $S / Y$ & $I / Y$ & $S / Y-I / Y$ & $S / Y$ & $I / Y$ & $S / Y-I / Y$ \\
\hline Australia & 0.245 & 0.267 & -0.022 & 0.217 & 0.231 & -0.014 \\
\hline Austria & 0.287 & 0.284 & 0.003 & 0.250 & 0.267 & -0.017 \\
\hline Belgium & 0.233 & 0.224 & 0.009 & 0.201 & 0.215 & -0.014 \\
\hline Canada & 0.218 & 0.231 & -0.013 & 0.209 & 0.235 & -0.026 \\
\hline Denmark & 0.220 & 0.248 & -0.028 & 0.194 & 0.228 & -0.034 \\
\hline Finland & 0.288 & 0.306 & -0.024 & 0.276 & 0.318 & -0.042 \\
\hline France & 0.251 & 0.250 & 0.001 & 0.229 & 0.232 & -0.003 \\
\hline Germany & 0.270 & 0.262 & 0.008 & 0.229 & 0.222 & 0.007 \\
\hline Greece & 0.222 & 0.252 & -0.030 & 0.247 & 0.276 & -0.029 \\
\hline Ireland & 0.197 & 0.225 & -0.028 & 0.234 & 0.272 & -0.038 \\
\hline Italy & 0.237 & 0.227 & 0.010 & 0.221 & 0.214 & 0.007 \\
\hline Japan & 0.366 & 0.358 & 0.008 & 0.305 & 0.317 & -0.012 \\
\hline Netherlands & 0.284 & 0.266 & 0.018 & 0.269 & 0.215 & 0.054 \\
\hline New Zealand & 0.230 & 0.255 & -0.025 & 0.205 & 0.275 & -0.070 \\
\hline Sweden & 0.243 & 0.241 & 0.002 & 0.195 & 0.211 & -0.016 \\
\hline United Kingdom & 0.189 & 0.193 & -0.004 & 0.177 & 0.190 & -0.013 \\
\hline United States & 0.188 & 0.188 & 0.000 & 0.171 & 0.179 & -0.008 \\
\hline
\end{tabular}

'Source: 'National accounts of the OECD countries: 1950-1979' (OECD, Paris, 1981). $S / Y$ is gross domestic savings divided by GDP. $I / Y$ is gross domestic investment divided by GDP.

Finland) to 0.054 (in the Netherlands) with a mean of -0.016 and a standard deviation of 0.025 .

For virtually every industrial country, the second half of the 1970s represented a time when domestic investment exceeded domestic savings. This in turn implied that net foreign investment was negative and therefore that the current account was in deficit. The negative net foreign investment for the industrial countries as a whole in these years was largely a reflection of the higher prices being paid for imported oil and the resulting surpluses of the OPEC countries.

Despite the substantial increase in the size and variability of international capital flows, the second half of the 1970s showed the same strong tendency for countries with high domestic savings rates to have high rates of domestic investment. Table 2 presents estimates of the basic investment equation,

$$
I_{i} / Y_{i}=\alpha+\beta\left[S_{i} / Y_{i}\right]+\varepsilon_{i},
$$

where $I_{i}$ is domestic investment in country $i, S_{i}$ is domestic savings, $Y_{i}$ is GDP, and $\varepsilon_{i}$ is a random disturbance. The equation is estimated with the sample of seventeen countries listed in table 1 and with the investment and 
savings ratios averaged over several different subperiods as well as for the entire 20-year period from 1960 through 1979.

The estimate for the second half of the 1970s indicates that an additional 'dollar' (pound, franc, mark, etc.) of domestic saving raised domestic investment by 0.865 dollars with a standard error of $0.185 .^{6}$ Comparison with the other subperiods indicates that the response of investment to savings was at least as high in this final period as in any of the earlier periods. This was true even though, as the lower $\bar{R}^{2}$ implies, there was more 'unpredictable' variation in domestic investment during this period. ${ }^{7}$

For the 20-year period as a whole, each extra 'dollar' of saving was associated with 0.796 additional dollars of investment. With a standard error of 0.112 , this is clearly significantly different from zero at any relevant probability level. The alternative null hypothesis, i.e., that the coefficient of $S / Y$ is 1.0 , can be rejected at a probability level of 10 percent, implying that capital does tend to flow to countries with low savings rates although certainly much less than perfect capital mobility would imply.

The first five equations reported in table 2 refer to gross saving and gross investment. Since capital accumulation depends on net investment, it is interesting to consider also the relation between net investment and net saving. Since this requires subtracting an estimate of depreciation from both variables, any error in measuring depreciation will tend to bias the estimated coefficient toward one. This potential bias is consistent with the result presented in the sixth equation of table 2 that shows a coefficient of 0.99 for the regression of the net investment ratio on the net savings rate.

If there were no problems of measuring savings, investment and international transactions, the difference between gross domestic savings and gross domestic investment would be equal to the balance on current account $(C A)$. This suggests that, instead of using the conventional national income account measure of domestic savings, the value of gross domestic savings could be defined as the sum of gross domestic investment and the current account balance: $\hat{S}=I+C A .^{8}$ The basic equation is reestimated for the decade of the 1970s with this derived measure of savings and presented in the final line of table 2 . The coefficient of 0.886 is only slightly higher than the previous estimate of 0.843 for this decade and show that this source of measurement error does not influence the basic result.

The estimation of eq. (1) with a cross-section of country averages implicitly assumes that each country's disturbance is purely random and uncorrelated

\footnotetext{
${ }^{6}$ If the equation is estimated in level form rather than ratio form, the coefficient is very close to one but this reflects the pure scale effect. Only ratio equations are therefore presented in this paper.

${ }^{7}$ These differences in domestic investment reflected such things as differences in the response of profitability and of capacity utilization to the 1973 OPEC shock and to the rising rates of inflation.

${ }^{8}$ This is the procedure used by Sachs (1981a).
} 
Table 2

The relation between domestic savings ratios and domestic investment ratios. ${ }^{\mathrm{a}}$

\begin{tabular}{lllccc}
\hline \multirow{2}{*}{ Equation } & $\begin{array}{l}\text { Sample } \\
\text { period }\end{array}$ & Definition & Const. & $S / Y$ & $\bar{R}^{2}$ \\
\hline 1 & $1975-1979$ & gross & 0.046 & 0.865 & 0.57 \\
& & & $(0.042)$ & $(0.185)$ & \\
2 & $1970-1974$ & gross & 0.048 & 0.826 & 0.73 \\
& & & $(0.033)$ & $(0.125)$ & \\
3 & $1970-1979$ & gross & 0.047 & 0.843 & 0.67 \\
& & & $(0.036)$ & $(0.146)$ & \\
4 & $1960-1969$ & gross & 0.059 & 0.779 & 0.82 \\
& & & $(0.022)$ & $(0.090)$ & \\
5 & $1960-1979$ & gross & 0.057 & 0.796 & 0.75 \\
& & & $(0.028)$ & $(0.112)$ & \\
6 & $1960-1979$ & net & 0.011 & 0.993 & 0.83 \\
& & & $(0.016)$ & $(0.111)$ & \\
7 & $1970-1979$ & gross; & 0.039 & 0.886 & 0.79 \\
& & derived & $(0.027)$ & $(0.112)$ & \\
& & & & &
\end{tabular}

aThe coeflicients refer to eq. (1) in the text. Standard errors are shown in parentheses. The 'gross' equations relate gross investment and saving while the 'net' equation relates net investment and saving.

with the savings ratio. If country investment rates do differ systematically for some reason that is not directly related to the savings ratio, eq. (1) should be replaced by an equation in which the constant term is allowed to differ among countries,

$$
I_{i} / Y_{i}=\alpha_{i}+\beta\left(S_{i} / Y_{i}\right)+\varepsilon_{i}
$$

If eq. (2) is the correct specification but eq. (1) is estimated, the coefficient of $\beta$ will be biased if $\alpha_{i}$ is correlated with the savings ratio.

This potential source of bias can be eliminated by extending the analysis to two observations for each country so that the constant values of the $\alpha_{i}$ 's can be eliminated. If eq. (2) is generalized by assuming that all investment ratios may shift by a constant amount $\delta$ between times $t$ and $t^{\prime}$, the new specification may be written as ${ }^{9}$

$$
I_{i t} / Y_{i t}-I_{i t^{\prime}} / Y_{i t^{\prime}}=\delta+\beta\left[S_{i t} / Y_{i t}-S_{i t^{\prime}} / Y_{i t^{\prime}}\right]+\varepsilon_{i t}-\varepsilon_{i t^{\prime}}
$$

${ }^{9}$ Although the $\alpha_{i}$ 's are eliminated by first differencing in this way, they can be estimated in a second step once $\beta$ and $\delta$ are estimated. The procedure is exactly equivalent to estimations with individual constant terms and two observations for each country. 
Defining the latter period as 1973 through 1979 (i.e., the years affected by the OPEC price shock) and the earlier period as the previous seven 'pre-OPEC' years implies an estimate of $\beta$ of 1.024 with a standard error of 0.227 , and an estimate of $\delta$ of 0.013 with a standard error of 0.005 . The $\bar{R}^{2}$ for this equation is 0.55 . Thus countries that increased their saving between the earlier period and the later period found that their investment increased on average by an equal amount between the two dates. There is certainly no support in this estimate for the view that increases in saving merely augmented the total world supply of funds and that such capital was allocated among countries in unconstrained pursuit of the highest rate of return. ${ }^{10}$

An alternative method of estimating eq. (2) is to use each of the annual observations in a pooled cross-section of time series. Using data for the entire 20-year period ${ }^{11}$ implies an estimate of 0.771 for $\beta$ with a standard error of 0.046 , very similar to the estimate of 0.796 shown in table 2 and obtained when the annual data are averaged to produce a single value for each country.

The similarity of the estimates with individual constant terms and with averaged data suggests that including the individual constant terms has little effect on the estimate of $\beta$. This is confirmed when eq. (1) is re-estimated with individual annual observations for all countries for the 20 -year period. The estimate of $\beta$ is 0.797 with a standard error of 0.031 , virtually identical to the estimates in table 2 .

The use of individual annual observations makes it possible to estimate a more general dynamic relation between savings and investment. When a lagged value of the savings ratio is added to the basic specification, its coefficient is relatively small and negative,

$$
\begin{aligned}
& I_{i t} / Y_{i t}=0.074+0.832\left(S_{i t}-Y_{i t}\right)-0.109\left(S_{i, t-1} / Y_{i, t-1}\right), \quad \bar{R}^{2}=0.68 . \\
& \text { (0.033) }
\end{aligned}
$$

The negative coefficient of the lagged savings variable suggests that investment does not adjust to savings gradually but overadjusts at first. The coefficients of further lagged values are smaller and not statistically significant. Finally, using the annual observations to estimate the average effect of year to year changes in saving among all countries indicates that

$$
I_{i t} / Y_{i t}-I_{i, t-1} / Y_{i, t-1}=-0.0001+0.863\left[S_{i t} / Y_{i t}-S_{i, t-1} / Y_{i, t-1}\right],
$$

$$
\bar{R}^{2}=0.60 .
$$

\footnotetext{
${ }^{10}$ The use of differences in saving and investment ratios may cause simultaneous equations bias that is not present in the estimates of lable 2. This is discussed in section 4.

"Some individual annual observations are missing. reducing the sample to 320 observations.
} 
Thus, even year to year increases in saving tend on average to be associated with increases in domestic investment in the saving country by approximately equal amounts. ${ }^{12}$

\section{Domestic savings and the components of international capital flows}

The basic investment equation can be rewritten in terms of net foreign investment and then used to analyze the relation between saving and the components of international capital flows. More specifically, subtracting the savings ratio from both sides of eq. (1) and multiplying by minus one yields

$$
\left(S_{i}-I_{i}\right) / Y_{i}=-\alpha+(1-\beta)\left(S_{i} / Y_{i}\right)-\varepsilon_{i}
$$

The national income accounts divide the excess of domestic saving over domestic investment into net foreign investment $(N F I)$ plus the statistical discrepancy in the savings-investment account $(S D S) .{ }^{13}$ Substituting this into eq. (6) implies

$$
N F I_{i} / Y_{i}=-\alpha+(1-\beta)\left(S_{i} / Y_{i}\right)-S D S_{i} / Y_{i}+\varepsilon_{i}
$$

If $S D S / Y$ were uncorrelated with the savings ratio, the estimate of $\beta$ obtained from eq. (7) would be exactly the same as the estimate obtained from eq. (1). In fact, there is a small positive association between the statistical discrepency ratio and the saving ratio in the sample, implying that the estimate of $\beta$ implied by estimating eq. (7) with the decade averages of $N F I / Y$ and $S / Y$ for 1970 through 1979 yields

$$
N F I_{i} / Y_{i}=\begin{aligned}
& 0.019+0.092\left(S_{i} / Y_{i}\right) \\
& (0.002)(0.785)
\end{aligned}
$$

The implied value of $\beta$ is 0.908 and therefore slightly higher than the estimate presented in table 2 . The coefficient of 0.092 implies that each extra 'dollar' of domestic saving causes a capital export of approximately 9 cents, but the very large standard error indicates that there is no statistically significant relation at all between net foreign investment and the domestic savings rate. ${ }^{14}$

Net foreign investment can itself be decomposed into the four major components of the international capital account (direct investment; portfolio

\footnotetext{
${ }^{12}$ Sections 4 and 5 show that the similarity of the coefficients based on long-term averages and annual changes may be subject to different interpretations.

${ }^{13}$ The net foreign investment of the United States thus represents the net investment abroad financed by savings in the United States.

${ }^{14}$ The much larger standard error in eq. (8) than in table 2 reflects the importance of the statistical discrepancy.
} 
investment; other long-term capital flows; and short-term capital flows) plus the total change in official reserves, the net errors and omissions, and a remaining minor category of the official settlements balance. The lack of a significant or substantial relation between domestic savings and net foreign investment as a whole could in principal reflect a balancing of positive and negative relationships among different components. For example, portfolio investment outflows might respond positively to the domestic savings rate only to be offset by changes in official reserves.

In fact, in each of the separate regressions, the coefficient of the savings ratio is always less than its standard error. There is no indication of a relation between sustained differences among countries in savings rates and any of the components of net foreign investment.

Net foreign investment is conceptually equal to the balance on current account. ${ }^{15}$ This suggests another decomposition that might be useful in analyzing the effect of intercountry savings differences. ${ }^{16}$ The relation between the current account balance and the savings ratio can be decomposed into the separate effects of savings on: merchandise exports; merchandise imports; other credits for goods, services and investment income; other debits for goods, services and investment income; private unrequited transfers; and public unrequited transfers. None of the six regression coefficients relating a current account component as a fraction of GDP to savings as a fraction of GDP had an absolute value as large as 0.1 and none was as large as its standard error. The lack of a significant relationship between the current account balance and savings reflects a lack of relation between each of its components and savings.

In short, the two decompositions that have been examined confirm the finding of section 2 that there is no relation between sustained differences in domestic savings rates and the external position of the country.

\section{Parameter identification and estimation with cross-country and time-series data}

The regression of the domestic investment ratio on the domestic savings ratio is an intuitively appealing test of the hypothesis of perfect capital mobility. Nevertheless, there are fundamental problems of identification and estimation that should be considered when it is recognized that both savings and investment are endogenous variables in an economic system. Feldstein and Horioka (1980) discussed the problem of simultaneous equations bias briefly and suggested that this was likely to be much less serious in estimates based on cross-country data averaged over long periods of time than in

\footnotetext{
${ }^{15}$ In practice, the two numbers differ because of such things as the allocation of special drawing rights and the statistical treatment of gold, extraordinary military transactions, etc.

${ }^{16}$ This analysis was suggested to me by Douglas Purvis.
} 
estimates based on annual time series for individual countries. As I noted in the introduction to the present paper, instrumental variable estimates suggested by a simultaneous equations model confirmed the ordinary least squares results.

The current section presents an explicit model and uses it to assess the regression of domestic investment on domestic saving as a test of the perfect capital mobility hypothesis and, when international capital mobility is less than perfect, as an estimate of the effect on domestic investment of endogenous shifts in domestic saving.

The simplest model that is adequate for this purpose requires a domestic investment function, a domestic savings function, a net foreign investment function, and a savings-investment equilibrium condition. I shall assume that all investment is financed by issuing bonds and that the demand for gross domestic investment $(I)$ can be written as a function of the domestic real interest rate $(r)$ plus a random shock $(u)$,

$$
I=\phi(r)+u
$$

with $\phi^{\prime}<0$. A similar specification of the domestic savings function,

$$
S=\psi(r)+v
$$

provides that the supply of saving is a non-decreasing function of the real interest rate $\left(\psi^{\prime} \geqq 0\right)$ plus a random shock.

Writing $N$ for net foreign investment (i.e., the net outflow of capital from the home country), the net capital outflow in response to a higher interest rate can be written as

$$
N=\eta(r)+e,
$$

where $\eta^{\prime}(r) \leqq 0$ implies that a higher real domestic interest rate reduces (or leaves unchanged if $\eta^{\prime}=0$ ) net foreign investment (or causes a greater net inflow from abroad, i.e., a negative net foreign investment), and $e$ is a random shock. Perfect capital mobility implies that $\eta^{\prime}=-\infty$. More generally, $\eta^{\prime}$ could differ between the short run and the long run and could vary among countries or time periods. Some reasons for such differences are discussed below.

Equilibrium in the goods market requires that domestic saving equal domestic investment plus net foreign investment, ${ }^{17}$

$$
S=I+N
$$

\footnotetext{
${ }^{17}$ In a simple theoretical model, this is equivalent to the equilibrium condition $S=I+X-M$, where $X$ is exports and $M$ is imports, since net foreign investment equals the current account surplus.
} 
These four equations determine values for the four endogenous variables $I, S$ $N$ and $r$ as functions of the three random distributions $u, v$ and $e$.

Substituting (9), (10) and (11) in (12) yields

$$
\psi(r)+v=\phi(r)+u+\eta(r)+e .
$$

Differentiating and solving for the change in the real interest rate implies:

$$
\mathrm{d} r=(\mathrm{d} u-\mathrm{d} v+\mathrm{d} e) /\left(\psi^{\prime}-\phi^{\prime}-\eta^{\prime}\right) .
$$

Since $\psi^{\prime} \geqq 0, \phi^{\prime}<0$ and $\eta^{\prime} \leqq 0$, the denominator is unambiguously positive. Thus the interest rate rises when there is a positive shock to domestic investment demand $(\mathrm{d} u>0)$ or to the domestic demand for net foreign investment $(\mathrm{d} e>0)$.

The effect of investment and savings shocks on net foreign investment can be obtained by combining eqs. (11) and (14),

$$
\mathrm{d} N=\eta^{\prime} \mathrm{d} r+\mathrm{d} e=\eta^{\prime}[\mathrm{d} u-\mathrm{d} v+\mathrm{d} e] /\left(\psi^{\prime}-\phi^{\prime}-\eta^{\prime}\right)+\mathrm{d} e .
$$

To interpret eq. (15), recall that $\mathrm{d} N>0$ means an increased capital outflow and that $\eta^{\prime} \leqq 0$. Thus an increase in domestic savings (dv>0) causes an increase in net foreign investment and, therefore, both a capital outflow and a current account surplus. With perfect capital mobility, $\eta^{\prime}=-\infty$ and $\mathrm{d} N / \mathrm{d} v$ $=1$; in this case, all of the additional domestic saving goes abroad. Similarly, even with a finite value of $\eta^{\prime}$, an increase in domestic investment $(\mathrm{d} u>0)$ causes a decrease in net foreign investment and therefore both a capital inflow and a current account deficit. ${ }^{18}$

This brief description of the international effects of shifts in domestic savings and investment has ignored the exchange rate movements that are likely to occur as part of the process of change. An autonomous increase in domest ic investment demand (or decrease in savings) will raise the domestic interest rate and cause a real appreciation of the home currency. With this increase in the exchange rate there is a current account deficit that accommodates the capital inflow. The model is consistent with this exchange rate behavior even though the exchange rate is not explicitly modelled.

Combining eqs. (9) and (14) shows the relation between domestic investment and a shift in domestic savings,

$$
\mathrm{d} I=\phi^{\prime}[\mathrm{d} u-\mathrm{d} v+\mathrm{d} e] /\left(\psi^{\prime}-\phi^{\prime}-\eta^{\prime}\right)+\mathrm{d} u,
$$

which implies

\footnotetext{
${ }^{18}$ This is the case discussed by Sachs $(1981 \mathrm{a}, \mathrm{b})$. I will return to his empirical results later in this section.
} 


$$
\mathrm{d} I / \mathrm{d} v=\phi^{\prime} /\left(\phi^{\prime}+\eta^{\prime}-\psi^{\prime}\right)
$$

With perfect capital mobility, $\eta^{\prime}=-\infty$ and $\mathrm{d} l / \mathrm{d} v=0$. At the other extreme, if international capital movements do not respond to the interest rate, $\eta^{\prime}=0$ and

$$
\mathrm{d} l / \mathrm{d} v=\phi^{\prime} /\left(\phi^{\prime}-\psi^{\prime}\right)
$$

Since $\phi^{\prime}<0$ and $\psi^{\prime} \geqq 0$, in this case $\mathrm{d} I / \mathrm{d} v \leqq 1$. If $\psi^{\prime}$ is 'small' relative to $-\phi^{\prime}$, i.e., if the interest elasticity of savings is small relative to the interest elasticity of investment, $\mathrm{d} l / \mathrm{d} v$ will be close to 1 .

Now that the theoretical relation between domestic saving and investment has been clarified it is possible to examine more explicitly the interpretation of the regression coefficient estimated by regressing the investment ratio on the savings ratio, i.e., the coefficient of eq. (1) estimated to be approximately one in the cross-country regressions reported in table 2 . The regression coefficient of eq. (1) is the ratio of the covariance between investment and saving divided by the variance of saving. The variance of savings can be approximated in terms of the current model in the following way. First, differentiate eq. (10) and eliminate $d r$ with the help of eq. (14) to obtain

$$
\mathrm{d} S=\psi^{\prime}[\mathrm{d} u-\mathrm{d} v+\mathrm{d} e] /\left(\psi^{\prime}-\phi^{\prime}-\eta^{\prime}\right)+\mathrm{d} v
$$

Now evaluate each of the derivatives at the mean value of the corresponding variable, square both sides, and take expectations. Since the expected value of the squared deviation from the mean is the variance.,

$$
\begin{aligned}
\sigma_{S S}= & \mathrm{E}(\mathrm{d} S)^{2} \\
= & {\left[\left(\phi^{\prime}+\eta^{\prime}\right)^{2} \sigma_{v v}+\left(\psi^{\prime}\right)^{2}\left(\sigma_{u u}+\sigma_{e e}+2 \sigma_{u e}\right)\right.} \\
& \left.-2 \psi^{\prime}\left(\phi^{\prime}+\eta^{\prime}\right)\left(\sigma_{u v}+\sigma_{e v}\right)\right] /\left(\psi^{\prime}-\phi^{\prime}-\eta^{\prime}\right)^{2} .
\end{aligned}
$$

Similarly, combining eqs. (16) and (19) yields an approximation for the covariance between $S$ and $I$.

$$
\begin{aligned}
\sigma_{S I}= & \mathrm{E}(\mathrm{d} S \cdot \mathrm{d} I) \\
= & \mathrm{E}\left[-\left(\phi^{\prime}+\eta^{\prime}\right) \mathrm{d} v+\psi^{\prime}(\mathrm{d} u+\mathrm{d} e)\right] \\
& \times\left[\left(\psi^{\prime}-\eta^{\prime}\right) \mathrm{d} u-\phi^{\prime}(\mathrm{d} v-\mathrm{d} e)\right] /\left(\psi^{\prime}-\phi^{\prime}-\eta^{\prime}\right)^{2} \\
= & {\left[-\left(\phi^{\prime}+\eta^{\prime}\right)\left(\psi^{\prime}-\eta^{\prime}\right) \sigma_{u v}+\phi^{\prime}\left(\phi^{\prime}+\eta^{\prime}\right)\left(\sigma_{v v}-\sigma_{e v}\right)\right.} \\
& \left.+\psi^{\prime}\left(\psi^{\prime}-\eta^{\prime}\right)\left(\sigma_{u u}+\sigma_{u e}\right)-\psi^{\prime} \phi^{\prime}\left(\sigma_{u v}-\sigma_{u e}+\sigma_{v e}-\sigma_{e e}\right)\right] /\left(\psi^{\prime}-\phi^{\prime}-\eta^{\prime}\right)^{2} .
\end{aligned}
$$


The regression of $I$ on $S$ can be approximated by the ratio of $\sigma_{S I}$ to $\sigma_{S S}$ or

$$
\begin{aligned}
\widehat{\beta}= & {\left[-\left(\phi^{\prime}+\eta^{\prime}\right)\left(\psi^{\prime}-\eta^{\prime}\right) \sigma_{u v}+\phi^{\prime}\left(\phi^{\prime}+\eta^{\prime}\right)\left(\sigma_{v v}-\sigma_{e v}\right)\right.} \\
& \left.+\psi^{\prime}\left(\psi^{\prime}-\eta^{\prime}\right)\left(\sigma_{u u}+\sigma_{u e}\right)-\psi^{\prime} \phi^{\prime}\left(\sigma_{u v}-\sigma_{u e}+\sigma_{v e}-\sigma_{e e}\right)\right] \\
& /\left[\left(\phi^{\prime}+\eta^{\prime}\right)^{2} \sigma_{v v}+\left(\psi^{\prime}\right)^{2}\left(\sigma_{u u}+\sigma_{e e}+2 \sigma_{u e}\right)-2 \psi^{\prime}\left(\phi^{\prime}+\eta^{\prime}\right)\left(\sigma_{u v}+\sigma_{e v}\right)\right] .
\end{aligned}
$$

With the help of eq. (22), we can now consider two questions. First, what is the implication of perfect capital mobility for the estimated coefficient $\hat{\beta}$ ? Second, what is the relation bet ween the estimated coefficient $\hat{\beta}$ and the effect on domestic investment of a shift in domestic saving $(\mathrm{d} I / \mathrm{d} v)$ ?

\subsection{Testing the perfect capital mobility hypothesis}

With perfect capital mobility, $\eta^{\prime}=-\infty$ and eq. (22) implies that

$$
\widehat{\beta}=\sigma_{u v} / \sigma_{v v}
$$

Thus perfect capital mobility is consistent with a positive parameter estimate only to the extent that the exogenous shifts in saving and investment are positively correlated. The likely magnitude of the correlation between savings and investment shifts depends on the nature of the data.

With time-series observations for an individual country, demand shocks could well make $\sigma_{u v}>0$. A downturn in economic activity might cause savings to be relatively low (because consumption depends on permanent income) and might also cause investment to be relatively low (because of low capacity utilization). Similarly, a supply shock that lowers income and profitability might also reduce both saving and investment. In either of these cases, the regression coefficient $\hat{\beta}$ could be positive and substantial even if there is perfect capital mobility. Conversely time-series data for an individual country could also have $\sigma_{u v}<0$; an exogenous temporary increase in the propensity to save $(\mathrm{d} v>0)$ could reduce aggregate output and thereby induce a decline in investment $(\mathrm{d} u<0)$. Estimates of $\beta$ based on time-series data for a single country are thus an unreliable basis for evaluating the hypothesis of perfect international capital mobility. ${ }^{19}$

In contrast, when the sample is a cross-section of countries and the observations for each country are averaged over a long period of time, there is no reason to expect any correlations between intercountry differences in

\footnotetext{
${ }^{19}$ Feldstein and Horioka estimated time-series regressions for individual countries and presented the results in NBER Working Paper No. 310, but did not include these time-series estimates in the published version [Feldstein and Horioka (1980)] because we concluded that the problem of simultaneous-equations bias meant that these individual country coefficients could not be interpreted as estimates of the effect on investment of exogenous changes in saving.
} 
the exogenous component of saving and in the exogenous component of investment. These intercountry saving differences reflect such things as the demographic structure of the population, the extent to which unfunded social security substitutes for private saving, the average level of government deficits, consumer credit and mortgage arrangements, and the long-term rise in income since current retirees were working and saving. Sustained differences in investment rates that are not just a reflection of savings differences (through the effect of saving on the cost of capital) reflect such things as business tax rules and the effects of unions on profitability. The intercountry variance in exogenous investment shifts is thus likely to be smaller than the intercountry variance in exogenous saving shifts $\left(\sigma_{u u}<\sigma_{v v}\right)$, and the covariance between the two is likely to be small or zero. If there is a non-zero covariance, there appears to be no presumption about its sign.

Eq. (23) shows that the estimated values of $\beta$ presented in table 2 are not consistent with perfect capital mobility if $\sigma_{u v}$ is zero or negative. Moreover, even if there is a positive covariance between exogenous savings differences and exogenous investment differences, the high values of the estimated $\beta$ 's are not consistent with perfect capital mobility if the variance of the savings shifts $\left(\sigma_{v v}\right)$ is large relative to the variance of the investment shifts $\left(\sigma_{u u}\right)$. To see this, note that eq. (23) can be rewritten as

$$
\begin{aligned}
\hat{\beta} & =\sigma_{u v} / \sigma_{v v} \\
& =\rho_{u v}\left(\sigma_{u u} \sigma_{v v}\right)^{\frac{1}{2}} / \sigma_{v v} \\
& =\rho_{u v}\left[\sigma_{u u} / \sigma_{v v}\right]^{\frac{1}{2}}
\end{aligned}
$$

where $\rho$ is the correlation between $u$ and $v$. Since $\rho \leqq 1$, with perfect capital mobility $\hat{\beta}$ is at most equal to the ratio of the standard deviation of the investment shifts to the standard deviation of the savings shifts. Since the observed estimates of $\beta$ are approximately one, eq. (24) shows that the evidence is not consistent with both perfect capital mobility and a low ratio of $\sigma_{u u} / \sigma_{v v}$.

It is easily shown that with perfect capital mobility the correlation between savings and investment is the same as the correlation between $u$ and $v .^{20}$ The observed correlations between saving and investment (i.e., the square root of the $R^{2}$ values reported in table 2) imply implausibily high correlations between the exogenous components of saving and investment.

In short, the identifying restriction in cross-country data that $\sigma_{u v} \leqq 0$ or

\footnotetext{
${ }^{20}$ With perfect capital mobility, the regression of saving on investment produces a coefficient equal to $\beta_{S I}=\sigma_{u v} / \sigma_{u u}$. Multiply this by $\beta_{t S}=\sigma_{u v} / \sigma_{v v}$ from eq. (23) and note that $\beta_{I S} \beta_{S I}$ $=\sigma_{u v}^{2} / \sigma_{u u} \sigma_{v v}=\rho_{u v}^{2}$. But the product of a regression coefficient and the coefficient for the reverse regression is equal to the squared correlation; i.e. $\beta_{I S} \beta_{S I}=\rho_{S I}^{2}$. Thus $\rho_{I S}^{2}=\rho_{u 1}^{2}$.
} 
that $\sigma_{u u} / \sigma_{v v}$ is small, is sufficient to permit interpreting the observed regressions of investment on savings presented in table 2 as strong evidence against perfect capital mobility. Alternatively, the restriction that the correlation between exogenous saving and investment differences is not greater than 0.5 also implies rejection of the perfect capital mobility hypothesis.

Estimates of $\beta$ based on a cross-country sample of changes in investment and saving provides a different type of evidence against the hypothesis of perfect capital mobility. In such a regression, any association between the levels of exogenous saving and investment effects is irrelevant. Instead, $\sigma_{u v}$ in eq. (23) must be interpreted as a relation between shifts in saving and shifts in investment. If countries in which the exogenous component of saving has increased between two dates (or two periods) tend to be those countries in which the exogenous component of investment has also increased, $\sigma_{u v}>0$ and the estimate of $\beta$ can be high even if there is perfect capital mobility. The danger of this covariance being large is greatest when the data can reflect changes from one phase of a business cycle to the next. It is therefore reassuring that the estimate of $\beta=1.04$ based on the changes in saving and investment reflected a comparison of two periods of six years (1968-1973 and 1974-1980) and that similar results were obtained by Feldstein and Horioka for a different set of years $(\beta=0.724$ with a standard error of 0.158 based on the changes for $1960-1969$ to $1970-1974) .^{21}$

\subsection{Estimating $\mathrm{d} I / \mathrm{d} v$}

Under what plausible conditions does the estimate of $\beta$ based on eq. (1) represent the effect on domestic investment of a shift in the exogenous factors influencing saving? Equivalently, when does the value of $\hat{\beta}$ given in eq. (22) equal the value of $\mathrm{d} I / \mathrm{d} v$ shown in eq. (17)? And, more generally, even when exact identification is not achieved, does $\widehat{\beta}$ tend to $\mathrm{d} I / \mathrm{d} v$ as certain limiting conditions are achieved?

Consider first the case in which saving rates are not sensitive to the interest rate $\left(\psi^{\prime}=0\right)$ and in which the exogenous differences in saving among countries are not correlated with exogenous differences in the domestic investment function or the net foreign investment function $\left(\sigma_{v u}=\sigma_{v e}=0\right)$. In this case, eqs. (22) and (17) imply that $\hat{\beta}=\phi^{\prime} /\left(\phi^{\prime}+\eta^{\prime}\right)=\mathrm{d} I / \mathrm{d} v$ and there is no simultaneous equation bias. $^{22}$

Although these assumptions may not hold exactly, they may be a reasonable approximation for cross-country data based on averages over extended periods. In this context, the interest elasticities of domestic

${ }^{21}$ Although the 1968-1973 to 1971-1980 comparison is influenced by the OPEC-induced slowdown, the comparison based on the earlier pair of periods is not biased by a supply shock.

${ }^{22}$ The assumptions of $\psi^{\prime}=0$ and $\sigma_{v e}=\sigma_{v u}=0$ make the model recursive with respect to $S$ and. therefore, make ordinary least squares an unbiased estimator. 
investment may be high relative to the interest elasticity of domestic savings. Similarly, the variance of domestic savings may be large relative to the covariance between exogenous savings differences and exogenous differences in investment and net foreign capital. The value of $\hat{\beta}$ in eq. (22) tends to $\mathrm{d} I / \mathrm{d} v$ as $\psi^{\prime} / \phi^{\prime}, \sigma_{u v} / \sigma_{v v}$ and $\sigma_{v e} / \sigma_{v v}$ all tend to zero.

An alternative specification places no restriction on the interest sensitivity of domestic savings but posits that the exogenous differences among countries in saving rates are large relative to the exogenous differences in domestic and foreign investment: thus $\sigma_{u u} / \sigma_{v v}$ and $\sigma_{e e} / \sigma_{v v}$ are both small and, therefore, $\sigma_{u v} / \sigma_{v v}, \sigma_{e v} \sigma_{v v}$ and $\sigma_{u e} / \sigma_{v v}$ are also small. Taking the limit as $\sigma_{v v}$ grows relative to the other variances and covariances implies that $\hat{\beta}$ tends to $\phi^{\prime} /\left(\phi^{\prime}+\eta^{\prime}\right)$. Since the true value of $\mathrm{d} l / \mathrm{d} v$ is $\phi^{\prime} /\left(\phi^{\prime}+\eta^{\prime}-\psi\right)$, the estimate overstates the true value. More specifically, the ratio of the sample estimate $(\hat{\beta})$ to the true value of $\mathrm{d} I / \mathrm{d} v$ is $\left(\phi^{\prime}+\eta^{\prime}-\psi^{\prime}\right) /\left(\phi^{\prime}+\eta^{\prime}\right)=1-\psi^{\prime} /\left(\phi^{\prime}+\eta^{\prime}\right)$. To express these as elasticities, let $\varepsilon_{S r}=\psi^{\prime} r / S$ be the saving elasticity, $\varepsilon_{I r}=-\phi^{\prime} r / I$ be the investment elasticity, and $\varepsilon_{N r}=-\eta^{\prime} r / N$ be the elasticity of net foreign investment. Thus

$$
\begin{aligned}
\hat{\beta} /(\mathrm{d} s / \mathrm{d} v) & =1+S \varepsilon_{s r} /\left(I \varepsilon_{I r}+N \varepsilon_{N r}\right) \\
& =1+(S / I) \varepsilon_{s r} /\left(\varepsilon_{l r}+(N / I) \varepsilon_{N r}\right) .
\end{aligned}
$$

Since $S / I$ is approximately one and $N / I$ is very close to zero, $\hat{\beta} /(\mathrm{d} I / \mathrm{d} v)$ is approximately one plus the ratio of $\varepsilon_{S r}$ to $\varepsilon_{I r}$. Most empirical research indicates that this ratio is low and, therefore, that the relative bias in $\hat{\beta}$ is small.

\subsection{The regression of savings on investment}

In an interesting pair of papers, Sachs (1981a, b) emphasized the response of international capital flows to temporary shifts in domestic propensities to invest. Sachs showed that countries that increased their share of investment in GDP between 1968-1973 and 1974-1979 also experienced substantial increases in net capital inflows, i.e., substantial decreases in net foreign investment. As a leading example of this, Sachs pointed to the major flow of capital into Norway that accompanied the Norwegian investment boom caused by Norway's discovery of North Sea oil.

Eq. (26) is typical of the type of results reported by Sachs, ${ }^{23}$

$$
\begin{array}{r}
\Delta[N F I / Y]_{i}=-0.227-0.561 \Delta[I / Y]_{i}, \\
(0.039)(0.148) \\
\bar{R}^{2}=0.46,
\end{array}
$$

\footnotetext{
${ }^{23}$ The dependent variable in Sachs' equation is actually the current account balance, but results for the current account and for $N F I$ are very similar.
} 
where $\Delta(N F I / Y)$ denotes the average $N F I / Y$ ratio in country $i$ in 1974-1979 minus that ratio in 1968-1973, and $\Delta(I / Y)$ denotes the corresponding change in the investment ratio. The paramenter estimate implies that one 'dollar' increase in domestic investment is associated with a net capital inflow of 0.56 dollars. Thus, treating $I / Y$ as the independent variable appears to imply that net capital flows play a much more significant role.

It would be wrong, however, to interpret -0.56 as an estimate of $\mathrm{d} N / \mathrm{d} u$. Unless the model is recursive with investment having no interest elasticity $\left(\phi^{\prime}\right.$ $=0)$ and no covariance between shifts in domestic investment and shifts in either saving or foreign investment $\left(\sigma_{u v}=\sigma_{u e}=0\right)$, the regression coefficient will not be an unbiased estimate of $\mathrm{d} N / \mathrm{d} u$. Since the equation is based on changes in domestic investment and changes in capital flows, such lack of covariance is unlikely. If, for example, a change in economic conditions between the two periods caused not only an exogenous increase in domestic investment but also a shift from foreign investment to domestic investment $\left(\sigma_{u e}>0\right)$, the absolute value of the estimated coefficient will overstate the induced capital inflow.

The ambiguity that results from using the change form of the regression can be avoided by examining the relation between the level of net foreign investment and the level of domestic investment. Since net foreign investment is essentially equal to the excess of domestic saving over domestic investment, an alternative specification is the regression of the domestic saving ratio on the domestic investment ratio, i.e., just reversing the left- and right-hand variables of eq. (1). The finding of a regression coefficient significantly less than one implies that intercountry differences in investment are associated with international capital flows to finance that investment. ${ }^{24}$

For the final five years of the data (1974-1979), the results with such a specification support Sachs' view. The regression coefficient in the regression of $S / Y$ on $I / Y$ is 0.66 with a standard error of 0.14 . Taken at face value, this implies that each extra dollar of exogenous domestic investment induces a capital inflow of 34 cents. $^{25}$

The most recent five years are, however, an unusual subperiod. For the entire 20-year period, the regression of $S / Y$ on $I / Y$ is 0.94 with a standard error of 0.13 . The point estimate thus implies that each dollar of additional domestic investment is associated with a net capital inflow of only 6 cents; with a standard error of 13 cents, this is clearly not significantly different from zero. Similarly, for the decade of the 1960 s the regression of $S / Y$ on $I / Y$ is 1.05 with a standard error of 0.12 , while for the first half of the 1970 s the regression coefficient is 0.088 with a standard error of 0.13 .

\footnotetext{
${ }^{24}$ There are of course still identification problems in interpreting the regression coefficient as an estimate of $\mathrm{d} S / \mathrm{d} u$ [and therefore making inferences about $\mathrm{d}(S-I) / \mathrm{d} u$ ] but these are similar to the ones discussed in sections 4.1 and 4.2.

${ }^{25}$ See the previous footnote.
} 
One possible interpretation is that conditions have changed in the mid1970s to make international capital flows more sensitive to differences in yields. To support this one might point to the end of the U.S. interest equalization tax in 1974, to the growth of the Eurodollar market and of the OPEC balances, and to the relaxation of restrictions on portfolio investment that were occurring in a variety of OECD countries [OECD (1980)]. Nevertheless, there is also the alternative possibility that the regression coefficient for this brief period provides a biased estimate of $\mathrm{d} S / \mathrm{d} u$ because of a temporary covariance among the 'exogenous' saving and investment factors during this unusual period. Only further time will tell.

It is clear, however, that for the previous fifteen years, the regressions of $S / Y$ on $I / Y$ as well as the regressions of $I / Y$ on $S / Y$ support the conclusion that higher levels of domestic investment do not induce foreign capital inflows but can only be financed by domestic saving.

\section{Portfolio adjustment and capital flows in the long run and the short run}

The analysis of section 4 indicates that the regression estimates are more relevant as a guide to the long-run response of international capital movements to changes in domestic savings and investment than to their short-run response. Coefficient estimates based on annual variations in savings and investment are subject to potentially severe simultaneous equation bias that is not present when annual observations are averaged over a decade or more, and the regression is estimated with a cross-country sample of these averages. The empirical estimates based on such data that were presented in sections 2 and 3 imply that, for the 1960 s and 1970 s as a whole, higher savings rates induce higher rates of domestic investment but virtually no increase in net foreign investment.

The behavior of capital flows in the short run may be quite different. Although the empirical analysis of sections 2 and 3 is not directly relevant, theoretical considerations suggest that the short run response of international capital flows to changes in domestic saving may be much greater than the long-run response. The essential reason for this is that the short-run capital flow is part of a once-for-all adjustment of the international portfolio. When the adjustment is complete, the rate of capital flow returns to a lower level governed by the rate of growth of the world capital stock and the share of international assets in the equilibrium portfolio. ${ }^{26}$

To make these ideas more precise, consider an investor who divides his portfolio between domestic and foreign assets. Domestic assets earn an

\footnotetext{
2"Although early models of Mundell (1968) and others did not distinguish between the adjustment phase and the steady state flow, the importance of distinguishing a temporary capital flow as part of a once-for-all capital stock adjustment has been recognized at least since Branson (1970). See also Branson (1979), Cumby and Obstfeld (1982), Girton and Henderson (1977) and Obsiteld (1981).
} 
uncertain return $r$, with subjective mean $\mu$ and subjective variance $\sigma_{o o}$. Foreign assets earn an uncertain return, $r^{*}$, with subjective mean $\mu^{*}$ and variance $\sigma_{* * *}$. The covariance between the returns is $\sigma_{* o}$. If the investor's preferences can be summarized by a utility function that is a quadratic function of the portfolio return, the investor will maximize

$$
\begin{aligned}
\left.\mathrm{Eu}\left[p r^{*}+(1-p) r\right)\right]= & p \mu^{*}+(1-p) \mu \\
& -\frac{1}{2} \gamma\left[p^{2} \sigma_{* *}+(1-p)^{2} \sigma_{o o}+2 p(1-p) \sigma_{o *}\right]
\end{aligned}
$$

where $\mathrm{E}$ is the expectations operator, $p$ is the proportion of the portfolio invested abroad, and $\gamma>0$ is a measure of risk aversion.

The first-order maximization condition implies that the optimal proportion invested abroad $\left(p^{*}\right)$ is

$$
p^{*}=\left[\mu^{*}-\mu-\gamma\left(\sigma_{o *}-\sigma_{o o}\right)\right] / \gamma\left(\sigma_{o o}+\sigma_{* *}-2 \sigma_{o *}\right),
$$

the denominator is $\gamma$ times the variance of $r-r^{*}$ and is therefore unambiguously positive. The numerator is easier to discuss if we replace $\sigma_{o *}$ by $\rho \lambda \sigma_{o o}$ where $\rho$ is the correlation between $r$ and $r^{*}$ and $\lambda^{2}=\sigma_{* *} / \sigma_{o o}$, the ratio of the foreign variance to the domestic variance. Thus

$$
p^{*}=\left[\mu^{*}-\mu-\gamma(\rho \lambda-1) \sigma_{o o}\right] / \gamma\left(\sigma_{o o}+\sigma_{* *}-2 \sigma_{o *}\right)
$$

It is clear that even if the foreign expected return exceeds the domestic return $\left(\mu^{*}>\mu\right)$, the investor may not wish to invest abroad, i.e., $p^{*} \leqq 0$. This can happen only if (1) there is a positive correlation between domestic and foreign rates of return (reflecting, for example, the international business cycle or common long-term trends in productivity and profitability) and (2) the subjective variance on the foreign return exceeds the subjective variance on the domestic return. The subjective variance on the foreign return may be very large because investors lack information about the foreign economy, its individual firms, accounting practices, etc. ${ }^{27}$ If $p^{*}<0$, the investor may be constrained to a corner solution with no foreign investment. It is clear that since $\lambda$ reflects subjective variances, investors in two countries may both decide not to invest in the other's securities.

Conversely, eq. (29) implies that $p^{*}$ may be greater than zero even if $\mu^{*}<\mu$ if foreign investing provides a useful diversification, i.e., if $\rho \lambda<1$. Thus

${ }^{27}$ A recent story in the Wall Street Journal reporting from Tokyo summarized the difficulty that foreign investors have in getting information on Japanese securities: "A foreigner here once asked a Japanese securities salesman where to get investment advice, and this is what he was told: "We have a saying: the better the English, the worse the analysis".' [Marcom (1982)]. European investors may do more portfolio investment in the United States than vice versa because of the greater ease with which detailed information can be obtained about U.S. firms. 
investors in two countries may both decide to invest in the other's securities even if they have accurate assessments of the expected rates of return.

A sustained increase in the domestic saving rate raises capital intensity at home and thereby depresses the expected rate of return, $\mu$. This unambiguously raises $p^{*}$, implying that some of the additional capital should be invested abroad. ${ }^{28}$ If the initial $p^{*}$ is negative, however, the increase in $p^{*}$ may still leave the actual $p$ at a constrained corner solution of $p^{*}=0$. In this case, domestic investors do not seek to transfer any of the additional saving abroad. The increased domestic saving may nevertheless lead to an increase in net foreign investment if foreign investors respond to the lower expected return by reducing their oversease investment. In terms of eq. (29), from the point of view of foreign investors $\mu^{*}$ has fallen, causing an unambiguous reduction in $p^{*}$. Again, however, if foreign investors were originally not investing abroad, the reduction in the expected return would have no effect. Thus portfolio considerations alone could explain why a change in domestic saving in one country would have no effect on its net foreign investment.

Ignoring the possibility of corner solutions, a sustained exogenous increase in domestic saving will, by reducing the expected domestic rate of return, raise $p^{*}$ and cause a capital outflow. This will be reinforced by foreign investors who respond to the lower expected return by reducing their overseas investment. The response of $p^{*}$ to the change in $\mu$ is inversely proportional to $\gamma\left(\sigma_{o o}+\sigma_{* *}\right.$ $\left.-2 \sigma_{o *}\right)$. The greater the risk aversion $(\gamma)$ or the uncertainty about domestic and foreign rates of return $\left(\sigma_{o o}\right.$ and $\left.\sigma_{* *}\right)$, the smaller will be the change in $p^{*}$. Thus, even for countries that do have overseas portfolio investments, the effect of a change in the expected return on domestic or foreign investment may be a relatively small change in the optimal allocation of assets between home and abroad. ${ }^{29}$

It is useful, however, to divide the response of international investment into two components. First, a sustained increase in the domestic saving rate alters $\mu^{*}-\mu$ and, therefore, changes $p^{*}$ for both domestic and foreign investors. There is then a relatively brief period during which portfolios are readjusted to the new optimal mix. ${ }^{30}$ During this readjustment there is a relatively large increase in the rate of net foreign investment. The shorter the time period during which the adjustment occurs, the greater will be the rate of net foreign investment per unit of time. Once the adjustment is complete, $p^{*}$ remains unchanged. As the national capital stocks at home and abroad grow over time with the economies, the fraction $p^{*}$ will flow abroad. Net foreign investment during this steady state growth will be the difference

\footnotetext{
${ }^{28}$ This is unambiguous only because I assume that the increase in domestic capital has no effect on the variance of the return or the risk aversion parameter.

${ }^{29} \mathrm{Hartman}(1980)$ presents evidence that international capital flows are large enough to affect rates of return on U.S. securities but not enough to equalize returns here and abroad.

${ }^{30}$ Although such a reallocation should in principle occur instantly, institutional reasons may cause the adjustment to take a year or more.
} 
between the steady state outflow of funds by domestic investment and the steady state inflow of funds from foreign investors. Although the evidence of sections 2 and 3 indicates that this long-run response to a sustained shift in domestic saving is quite small, the short-run response during a brief period of transition could be quite substantial.

\section{Concluding comments}

The evidence and analysis in this paper support the earlier findings of Feldstein and Horioka (1980) that sustained increases in domestic savings rates induce approximately equal increase in domestic investment rates. Although this limited extent of international capital mobility is consistent with the portfolio model developed in section 5, there are clearly other aspects of both international portfolio investment and international direct investment that should be taken into account in explaining the observed mobility.

Government policies establish the framework for private international investing. Governments of OECD countries have sought to restrict both capital inflows and capital outflows, including both direct and portfolio investment. Even the United States, perhaps the most liberal of the OECD countries in its attitude to capital movements, restricts the class of institutions that can invest abroad and thereby reduces the total volume and sensitivity of foreign investment. It would be useful to examine the capital restriction policies in detail, to evaluate their effectiveness and to understand the reasons why governments may choose to restrict international capital movements. ${ }^{31}$

More generally, although net capital flows do not appear to be sensitive to domestic saving rates, a stable pattern of net capital flows exists. It would be desirable to examine the reasons for this stable pattern and, in particular, to resolve the puzzling fact that substantial gross capital flows produces relatively small net capital flows.

\footnotetext{
${ }^{31}$ One such reason, the ability of foreign governments to capture the tax revenue of foreign investment, is discussed in Feldstein (1982).
}

\section{References}

Branson, W.H., 1970, Monetary policy and the new view of international capital movements, Brookings Papers on Economic Activity, 235-270.

Branson, W.H., 1979, Exchange rate dynamics and monetary policy, in: A. Lindbeck, ed., Inflation and unemployment in open economics (North-Holland, Amsterdam).

Cumby, R.E. and M. Obstfeld, 1982, International interest-rate and price-level linkages under 'flexible exchange rates: A review of recent evidence', Lecture given al the NBER conference on exchange rate theory and practice, Bellagio, Italy. 
Feldstein, M., 1977, Social security and private savings: International evidence in an extended life-cycle model, in: M. Feldstein and R. Inman, eds., The economics of public services, An International Economic Association conference volume.

Feldstein, M., 1982, International tax rules, restrictions on capital mobility and domestic savings policies, forthcoming.

Feldstein, M. and C. Horioka, 1980, Domestic savings and international capital flows, The Economic Journal 90, 314-329.

Frisch, D., 1981, Issues in the taxation of foreign source income, NBER working paper no. 798 (NBER, Cambridge, MA).

Ginton, L. and D.W. Henderson, 1977, Central bank operations in foreign and domestic assets under fixed and flexible exchange rates, in: P.B. Clark, D. Logue and R. Sweeney, eds., The effects of exchange rate adjustments (U.S. Government Printing Office, Washington, DC).

Harberger, A.C., 1978, Perspectives on capital and technology in less developed countries, in: M.J. Artis and A.R. Nobay, eds., Contemporary economic analysis (London).

Harberger, A.C., 1980, Vignettes on the world capital market, American Economic Review, 331337.

Hartman, D., 1980, International effects on the U.S. capital market, NBER working paper no. 581 (NBER, Cambridge, MA).

Hartman, D., 1981, Domestic tax policy and foreign investment: Some evidence, NBER working paper no. 784 (NBER, Cambridge, MA).

Marcom, J. Jr., 1982, Brokers intensify stock studies in Tokyo as more foreign investors look to Japan, Wall Street Journal, May 7.

Modigliani, F., 1970, The life cycle hypothesis of saving and intercountry differences in the saving ratio, in: W.A. Eltis et al., eds., Induction, growth and trade, Essays in honor of Sir Roy Harrod (Clarendon Press, Oxford).

Mundell, R.A., 1960, The monetary dynamics of international adjustment under fixed and flexible exchange rates, Quarterly Journal of Economics 74, 227-257.

Obstifeld, M., 1980, Imperfect asset substitutability and monetary policy under fixed exchange rates, NBER working paper no. 485 (NBER, Cambridge, MA).

OECD, 1980, Experience with controls on international portfolio operations in shares and bonds (OECD, Paris).

OECD, 1981, National accounts of the OECD countries: 1950-1979, Vols. 1 and 2 (OECD, Paris).

Sachs, J., 1981a, The current account and macroeconomic and macroeconomic adjustment in the 1970s, Brookings Papers on Economic Activity, 201-282.

Sachs, J.D., 1981b, Aspects of the current account behavior of OECD economies, NBER working paper no. 859 (NBER, Cambridge, MA). 